\title{
OXYGEN UPTAKE DURING MINERALIZATION OF HUMIC SUBSTANCES FROM INFERNÃO LAGOON (SÃO PAULO, BRAZIL)
}

\author{
CUNHA-SANTINO, M. B. ${ }^{1}$ and BIANCHINI JR., I. ${ }^{1,2}$ \\ ${ }^{1}$ Programa de Pós-graduação em Ecologia e Recursos Naturais, Universidade Federal de São Carlos, \\ Rodovia Washington Luiz, km 235, C.P. 676, CEP 13565-905, São Carlos, SP, Brazil \\ ${ }^{2}$ Departamento de Hidrobiologia, Universidade Federal de São Carlos, Rodovia Washington Luiz, km 235, \\ C.P. 676, CEP 13565-905, São Carlos, SP, Brazil \\ Correspondence to: Irineu Bianchini Jr., Universidade Federal de São Carlos, Departamento de Hidrobiologia, \\ Rodovia Washington Luiz, km 235, C.P. 676, CEP 13565-905, \\ São Carlos, SP, Brazil, e-mail: irineu@power.ufscar.br \\ Received February 28, 2003 - Accepted June 27, 2003 - Distributed August 31, 2004
}

(With 2 figures)

\begin{abstract}
Assays were carried out to evaluate the dissolved oxygen uptake resulting from mineralization of humic substances (fulvic acid (FA) and humic acid (HA)) from different sources: sediment, dissolved organic matter (DOM) of 120-day decomposed aquatic macrophyte (Scirpus cubensis and Cabomba piauhyensis), and lagoon DOM. The experiments were also aimed at estimating the oxygen uptake coefficient of the mineralization. About 20-30 mg of substrate were added to 1.1 liters of water from Infernão Lagoon $\left(21^{\circ} 33^{\prime}\right.$ to $21^{\circ} 37^{\prime} \mathrm{S} ; 4^{\circ} 45^{\prime}$ to $\left.47^{\circ} 51^{\prime} \mathrm{W}\right)$. The solutions were aerated and the dissolved oxygen (DO) was monitored during 40 days. Dissolved organic carbon (DOC) and particulate organic carbon (POC) were estimated after 80 days of the experiment. Anaerobic processes were avoided by aerating the solutions. The results were fitted to a first-order kinetics model, from which the uptake of oxygen parameters was obtained. Oxygen consumption (OC) ranged from $4.24 \mathrm{mg} \mathrm{L}^{-1}$ (HA - S. cubensis) to $33.76 \mathrm{mg} \mathrm{L}^{-1}$ (FA - sediment). The highest deoxygenation coefficient $\left(\mathrm{k}_{\mathrm{D}}\right)$ was observed during mineralization of FA - DOM (0.299 day $\left.^{-1}\right)$, followed in decreasing order by FA - S. cubensis, HA - sediment, HA - S. cubensis, FA - sediment, and FA - C. piauhyensis $\left(0.282 ; 0.255 ; 0.178 ; 0.130\right.$, and 0.123 day $^{-1}$, respectively). The carbon analyses indicated that the FA and HA samples at the end of the experiment presented a decay that varied from $15.23 \%$ to $42.35 \%$ and that the FA and HA conversions into POC were relatively low (from $0.76 \%$ to $3.94 \%$ ).
\end{abstract}

Key words: humic substances, oxygen uptake, aerobic conditions, Infernão Lagoon (Brazil).

\section{RESUMO}

\section{Consumo de oxigênio durante a mineralização de substâncias húmicas provenientes da lagoa do Infernão (São Paulo, Brasil)}

Foram realizados ensaios a fim de avaliar o consumo de oxigênio dissolvido resultante da mineralização de substâncias húmicas (ácido fúlvico - $\mathrm{AF}$ e ácido húmico - $\mathrm{AH}$ ) provenientes de diferentes fontes: sedimento, matéria orgânica dissolvida (MOD) resultante de 120 dias de degradação de macrófitas aquáticas (Scirpus cubensis e Cabomba piauhyensis) e MOD da lagoa do Infernão. O experimento também teve por objetivo estimar os coeficientes de consumo de oxigênio durante a mineralização. Cerca de 20-30 mg de substratos foram adicionados a 1,1 litro de água da lagoa do Infernão (21 ${ }^{\circ} 33^{\text {' }}$ a $21^{\circ} 37^{\prime} \mathrm{S} ; 4^{\circ} 45^{\prime}$ a $47^{\circ} 51^{\prime} \mathrm{W}$ ). As soluções foram aeradas e o oxigênio dissolvido (OD) foi monitorado durante 40 dias. O carbono orgânico dissolvido (COD) e o particulado (COP) foram estimados após 80 dias. Os processos anaeróbios foram evitados aerando-se as soluções. Os resultados foram ajustados a um modelo cinético de primeira ordem e os parâmetros do consumo de oxigênio foram obtidos. $\mathrm{O}$ 
consumo de oxigênio (CO) variou de 4,24 $\mathrm{mg} \mathrm{L}^{-1}$ (AH - S. cubensis) a 33,76 $\mathrm{mg} \mathrm{L}^{-1}$ (AF - sedimento). $\mathrm{O}$ coeficiente de desoxigenação mais elevado $\left(\mathrm{k}_{\mathrm{D}}\right)$ foi observado durante mineralização do $\mathrm{AF}-\mathrm{MOD}$ $\left(0,299 \mathrm{dia}^{-1}\right)$, seguido em ordem decrescente: AF - S. cubensis, AH - sedimento, AH - S. cubensis, $\mathrm{AF}$ - sedimento e AF - C. piauhyensis $\left(0,282 ; 0,255 ; 0,178 ; 0,130\right.$; e $0,123 \mathrm{dia}^{-1}$, respectivamente). As análises de carbono indicaram que o $\mathrm{AF}$ e o $\mathrm{AH}$ ao final do experimento apresentaram decaimento de $15,23 \%$ a $42,35 \%$ e que as conversões de $\mathrm{AF}$ e de $\mathrm{AH}$ em COP foram relativamente baixas $(0,76 \%$ a $3,94 \%)$.

Palavras-chave: substâncias húmicas, consumo de oxigênio, condições aeróbias, lagoa do Infernão (Brasil).

\section{INTRODUCTION}

The littoral zone and its autochthonous productivity have a significant impact on the metabolism of lake ecosystems. The inputs of littoral organic matter through decomposition are often greater than those from planktonic and allochthonous sources (Godshalk \& Wetzel, 1978) and aquatic macrophytes often dominate the largest biomass. Interactions among rooted aquatic plants, sediments, and water may result in a net increase or decrease in nutrient levels (Wetzel, 1992). Dead vascular plant material begins to lose soluble organic and inorganic materials shortly after immersion in water. The general pattern of leaching from immersed aquatic plants includes fast loss in the initial 24 hours followed by a gradual decline for an extended period (Pieczynska, 1993; Wetzel, 1995; Cunha \& Bianchini Jr., 1998). With the loss of cellular integrity upon senescence, the dead plant material may readily release stored nutrients into the water-column during its decomposition (Wetzel, 1995).

The decay of organic matter may take place in an aerobic or anaerobic environment. It is usually acknowledged in kinetics studies that substrate disappearance is proportional to product formation. For aerobic processes, it is generally assumed that the formation of products such as $\mathrm{CO}_{2}$ is proportional to oxygen uptake. This process is similar to the chemical reactions and stoichiometric relations usually regarded as the basis for the process of formation and oxidation of organic resources (Jprgensen, 1986; Chapra \& Reckhow, 1983; Stumm \& Morgan, 1981).

The present study discusses mineralization of humic substances usually found in aquatic systems firm the aquaticplantsScirpus cubensis and Cabomba piauhyensis, dissolved organic matter (DOM), and sediment through the kinetics of oxygen uptake.

\section{MATERIALS AND METHODS}

\section{Description of the area}

Infernão Lagoon is one of the many oxbow lakes in Mogi-Guaçu river floodplain (State of São Paulo, Brazil; $21^{\circ} 33^{\prime}$ to $21^{\circ} 37^{\prime} \mathrm{S}$ and $47^{\circ} 45^{\prime}$ to $\left.47^{\circ} 51^{\prime} \mathrm{W}\right)$. Its area measures 3.05 ha, with an average $2.1 \mathrm{~m}$ depth and maximum $4.9 \mathrm{~m}$ depth (Nogueira et al., 2000). Scirpus cubensis Poepp \& Kunth is the most common species of emergent aquatic macrophyte in Infernão Lagoon. The hydrological cycle of this region is marked by high water periods, when surrounding areas are flooded, and by a distinct dry season. Nowadays, the floating stands of $S$. cubenis directly influence temperature and dissolved oxygen distribution in the water column in the littoral zone, since stratification occurs during the entire hydrological cycle (Nogueira et al., 2000). Due to intense occupation by Scirpus cubensis, Salvinia auriculata, and Cabomba piauhyensis in this lagoon, great amounts of humic compounds are produced during decomposition. A study on the decomposition process showed that microorganisms may be considered efficient vectors in carbon removal from humic substances. In this case, conversion of humic substances (HS) into particulate organic carbon (microorganisms) averaged $13.6 \%$ for fulvic acid (FA) and $15.7 \%$ for humic acid (HA) (Cunha-Santino \& Bianchini Jr., 2002).

\section{Isolation of humic substances}

The HS was extracted at Infernão Lagoon from sediment samples, dissolved products of decomposed aquatic macrophyte, and DOM from Infernão Lagoon. They were isolated using analytical procedures (Hayes \& Swift, 1978; Stevenson, 1982; Leenheer, 1981; Malcolm, 1985; Thurman, 1985), considering the solubility in acid and alkaline solutions. For HS from the sediment, 
the technique consisted of: i) alkaline extraction (sodium hydroxide: $0.5 \mathrm{~mol} \mathrm{~L}^{-1}$ ); ii) centrifugation; iii) lowering the $\mathrm{pH}$ to $\approx 2$ with chloride acid, and iv) FA and HA fractionation by centrifugation (1 h, $978.25 \mathrm{~g}$ ). The HS from sediment was obtained by successive extractions with sodium hydroxide under shaking. After 24 hours, the material soluble in alkalis was removed and stored. The initial collected water from the lagoon $(\approx 130 \mathrm{~L})$ was concentrated at a low temperature $\left(40^{\circ} \mathrm{C}\right)$ to a final volume of $2 \mathrm{~L}$. The HS extraction from DOM was carried out as mentioned above for the sediment.

For HS generation from aquatic macrophytes, the plant material (Scirpus cubensis and Cabomba piauhyensis) and water samples were collected from Infernão Lagoon. The plant material was washed under tap water to remove attached matter, and then oven-dried at $45^{\circ} \mathrm{C}$; after drying, the samples were crushed. For humic substances formation, the plant material was placed in acid-washed 5-liter flasks with filtered (through glass wool) lagoon water, producing a $10 \mathrm{~g} \mathrm{~L}^{-1}$ dry weight concentration. The flasks were kept aerated and incubated at room temperature. After 120 days, flask contents were separated into DOM (whole leachate) and particulate organic matter (POM). The HS was isolated from the 120-day leachate derived from the plant decomposition by the same procedures used in isolating HS from sediment and DOM.

\section{Oxygen uptake assays and carbon determination}

The FA and HA samples from the sediment, the DOM of 120-day decomposed aquatic macrophyte (S. cubensis and C. piauhyensis), and lagoon DOM were incubated at $21.0^{\circ} \mathrm{C} \pm 0.6$ in flasks containing filtered (through glass wool) lagoon water, under aerobic conditions. This required oxygenation with clean air during 1 hour to keep the dissolved oxygen (DO) near saturation. When the DO concentrations neared $2.0 \mathrm{mg} \mathrm{L}^{-1}$, the solutions were oxygenated again, until the oxygen reached the saturation value; this procedure avoided anaerobiosis in the solutions. Table 1 shows the initial concentration (carbon-based) of the solutions ( $\mathrm{TOC}_{\mathrm{i}}$ ). Carbon concentrations were determined by high-temperature combustion with a Shimadzu TOC-5000A analyzer. Oxygen uptake was verified during 40 days. The DO concentrations were estimated with a DOmeter (Metrohm Herisau AGCH-9100/E-635). After a 80$\mathrm{d}$ period, final total organic carbon $\left(\mathrm{TOC}_{\mathrm{f}}\right)$ concen- trations were determined. Final dissolved organic carbon $\left(\mathrm{DOC}_{\mathrm{f}}\right)$ was also estimated after filtering the solutions through a $0.22 \mu \mathrm{m}$ ester cellulose membrane (Millipore GS). The difference between TOC $_{f}$ and $\mathrm{DOC}_{\mathrm{f}}$ gave the particulate organic carbon concentrations (POC).

\section{Kinetic model}

During aerobic mineralization, the oxygen consumed is inferred to correspond to the $\mathrm{CO}_{2}$ amount formed (Stumm \& Morgan, 1981; Chapra $\&$ Reckhow, 1983). The oxygen consumption corresponds to FA and HA decay and $\mathrm{CO}_{2}$ formation. We considered, therefore, that oxygen consumption is directly related with organic resource oxidation, and that this process can be represented by firstorder kinetics models (Brezonik, 1993; Henze et $a l ., 1997)$. Thus, the variation in oxygen decay (Equation 1) and its uptake (Equation 2) can be described according to the following equations:

$$
\frac{d[D O]}{d t}=-k_{D} D O
$$

where:

$[\mathrm{DO}]=$ change in oxygen concentration per unit of time $\left[\mathrm{mg} \mathrm{L}^{-1}\right.$;

$\mathrm{k}_{\mathrm{D}}=$ deoxygenation rate constant $\left[\mathrm{day}^{-1}\right]$;

$\mathrm{t}=$ time [day $]$.

$$
\frac{d O C}{d t}=k_{D} D O-k_{R} O C
$$

where:

OC =oxygen uptake $\left[\mathrm{mg} \mathrm{L}^{-1}\right]$;

$\mathrm{k}_{\mathrm{R}}=$ reaeration rate constant $\left[\right.$ day $\left.^{-1}\right]$ derived from stirring during DO determination.

Equations 3 to 6 refer to the proposed kinetic model for humic substance decomposition. The parameterization of the reaction coefficients $\left(\mathrm{k}_{1}, \mathrm{k}_{2}\right.$, and $\mathrm{k}_{3}$ ) arises from the $\mathrm{k}_{\mathrm{D}}$ (deoxygenation rate constant) calculation and the carbon concentration results. The principles adopted by the model (Equation 3 to 6) regard the $\mathrm{k}_{\mathrm{D}}$ and $\mathrm{k}_{\mathrm{T}}$ (global decay rate constant) as similar. The $\mathrm{k}_{\mathrm{D}}$ values were obtained by fitting the oxygen uptake results, as shown in Equation 2, according to Levenberg-Marquardt iterative algorithm (Press et al., 1993). Therefore, considering the concepts related with the parallel 
reaction model (Levenspiel, 1972), the mineralized coefficient $\left(\mathrm{k}_{1}\right)$ was estimated from net mineralized carbon $(\mathrm{IN})\left(\mathrm{k}_{1}=\left(\left(\mathrm{TOC}_{\mathrm{i}}-\mathrm{TOC}_{\mathrm{f}}\right) / \mathrm{TOC}_{\mathrm{i}}\right) * \mathrm{k}_{\mathrm{T}}\right)$; the POC formation coefficient $\left(\mathrm{k}_{2}\right)$ was obtained from the difference between $\mathrm{TOC}_{\mathrm{f}}$ and $\mathrm{DOC}_{\mathrm{f}}\left(\mathrm{k}_{2}=\left(\left(\mathrm{TOC}_{\mathrm{f}}-\right.\right.\right.$ $\left.\left.\mathrm{DOC}_{\mathrm{f}}\right) / \mathrm{TOC}_{\mathrm{i}}\right) * \mathrm{k}_{\mathrm{T}}$ ); and the refractory humic substance (RHS) formation coefficient $\left(\mathrm{k}_{3}\right)$ was calculated from the proportion between $\mathrm{DOC}_{\mathrm{f}}$ and $\mathrm{TOC}_{\mathrm{i}}\left(\mathrm{k}_{3}=\left(\mathrm{DOC}_{\mathrm{f}} / \mathrm{TOC}_{\mathrm{i}}\right) \times \mathrm{k}_{\mathrm{T}}\right)$.

The stoichiometric coefficients (SC) were estimated from the relations between maximum consumed oxygen (observed from the $\mathrm{OC}$ result fittings) and the amount of IN $\left(\mathrm{TOC}_{\mathrm{i}}-\mathrm{TOC}_{\mathrm{f}}\right)$.

$$
\begin{gathered}
I N=[D O C] \frac{k_{1}}{k_{T}}\left(1-e^{-k_{T^{t}}}\right) \\
O C=S C . I N \\
P O C=[D O C] \frac{k_{2}}{k_{T}}\left(1-e^{-k_{T} t}\right) \\
R H S=[D O C] \frac{k_{3}}{k_{T}}\left(1-e^{-k_{T} t}\right)
\end{gathered}
$$

where:

$\mathrm{OC}=$ oxygen uptake $\left[\mathrm{mg} \mathrm{L}^{-1}\right]$;

$\mathrm{SC}=$ stoichiometric coefficient $(\mathrm{O} / \mathrm{C})$;

RHS = refractory humic substance;

DOC $=$ initial concentration of DOC;

POC $=$ particulate organic carbon $(\approx$ micror ganisms);

IN = inorganic products (in carbon basis);

$\mathrm{k}_{\mathrm{T}}=$ global decay rate constant $\left[\right.$ day $\left.^{-1}\right]$ which

is similar to $\mathrm{k}_{\mathrm{D}}$ and $\mathrm{k}_{\mathrm{T}}=\mathrm{k}_{1}+\mathrm{k}_{2}+\mathrm{k}_{3}$;

$\mathrm{k}_{1}=$ mineralization rate constant $\left[\right.$ day $\left.^{-1}\right]$;

$\mathrm{k}_{2}=$ POC production rate constant $\left[\mathrm{day}^{-1}\right]$;

$\mathrm{k}_{3}=$ RHS production rate constant $\left[\mathrm{day}^{-1}\right]$.

\section{RESULTS}

The kinetics of oxygen uptake from aerobic mineralization of HS (FA and HA) from decaying aquatic macrophytes, sediment samples, and DOM are shown in Fig. 1, where the oxygen uptake effect deriving from the water samples (Control) from the Infernão Lagoon was subtracted. The oxygenation effect on the solutions due to the experimental procedure employed during oxygen uptake measurement was detected using Equation 2. This interference was neutralized by considering in the fittings the average reaeration coefficient $\left(k_{R}=0.02\right.$ day $\left.^{-1}\right)$. Table 1 shows that the OC for the whole 40 days of the experiment ranged from $4.24 \mathrm{mg} \mathrm{L}^{-1}$ for $\mathrm{HA}$ (S. cubensis) to 33.76 $\mathrm{mg} \mathrm{L}^{-1}$ for FA (sediment).

Calculations made from the deoxygenation coefficients $\left(\mathrm{k}_{\mathrm{D}}\right)$ obtained from the kinetic fittings provide the half-time $\left(t_{1 / 2 \mathrm{D}}\right)$ of the aerobic mineralization process. The $\mathrm{k}_{\mathrm{D}}$ ranged from 0.123 to 0.299 day $^{-1}$. The $t_{1 / 2 \mathrm{D}}$ showed a variation of between 2.31 and 5.62 days (Table 1). The largest $\mathrm{k}_{\mathrm{D}}$ was observed during FA - DOM mineralization $\left(0.299\right.$ day $\left.^{-1}\right)$, followed in decreasing order by FA (S. cubensis), HA (sediment), HA (S. cubensis), FA (sediment), and FA $(C$. piauhyensis $)(0.282 ; 0.255 ; 0.178 ; 0.130$; and 0.123 day $^{-1}$, respectively). For FA, the largest $\mathrm{k}_{\mathrm{D}}$ was observed for FA - DOM $\left(0.299\right.$ day $\left.^{1}\right)$, which presented a $t_{1 / 2 \mathrm{D}}$ of 2.31 days. For HA, the largest coefficient was 0.255 day $^{-1}\left(\mathrm{t}_{1 / 2 \mathrm{D}}=2.71\right.$ days $)$ from the sediment. On the other hand, the oxidation of FA (C. piauhyensis) presented the lowest coefficient $\left(0.123\right.$ day $^{-1}$ and $t_{1 / 2 \mathrm{D}}=5.62$ days $)$.

For estimating the global stoichiometric of the total amount of oxidized carbon for each substrate, $\mathrm{OC}$ total value was divided by the difference between the $\mathrm{TOC}_{\mathrm{i}}$ and $\mathrm{TOC}_{\mathrm{f}}$ concentrations (Table 1). The stoichiometric coefficients were used to convert the experimental data for oxygen uptake $\left(\mathrm{mg} \mathrm{L}^{-1}\right)$ into an equivalent in carbon $(\mathrm{g})$. Next, the oxygen uptake stoichiometric was related to the amount of oxygen used during carbon oxidation. Table 1 shows the global stoichiometric averages from the HA and FA mineralization process, where the ratio $\mathrm{O} / \mathrm{C}$ ranged from 0.67 to 2.38 .

The data from the carbon analyses indicated that the HS samples at the end of the experiment presented decay varying from $15.23 \%$ to $42.35 \%$ (Table 2). The FA and HA conversions into POC were relatively low (from $0.76 \%$ to $3.94 \%$ ). The resource accounting for the main contribution to POC formation was FA - DOM, followed by FA $(S$. cubensis) (3.15\%) and FA (sediment) (1.41\%). The other substrata supported conversions of below $1.0 \%$.

Using $\mathrm{k}_{\mathrm{D}}$ values, it was possible to estimate the mineralization coefficients $\left(\mathrm{k}_{1}\right)$, POC formation $\left(\mathrm{k}_{2}\right)$, and formation of RHS $\left(\mathrm{k}_{3}\right)$, which were defined according to the kinetics model illustrated 
in Fig. 2 and represented mathematically in equations 3 through 6 . The $\mathrm{k}_{1}, \mathrm{k}_{2}$, and $\mathrm{k}_{3}$ values are shown in Table 2.

\section{DISCUSSION}

The oxygen uptake is stoichiometrically related to $\mathrm{CO}_{2}$ and biomass formation (Characklis, 1990). Several studies have estimated the temporal evolution of oxygen consumption to assess the metabolic activity of microorganisms involved in the mineralization process of organic resources (McAvoy et al., 1998; Gotvajn \& Zagorc-Koncan, 1999). Earlier studies by Ryhänen (1968) asserted that during HS aerobic mineralization, the amount of oxygen consumed corresponds to the $\mathrm{CO}_{2}$ amount generated. The data on accumulated oxygen uptake presented here $\left(\mathrm{OC}\right.$, in Table 1) represent $\mathrm{CO}_{2}$ formation from HS decay. From the standpoint of kinetics, oxygen uptake in HS mineralization is similar to that of several organic substrata. Thus, at the beginning of the process, the mineralization displayed an accentuated DO consumption tendency. After a period of 8 days, in all flasks a gradual decrease was observed in oxygen uptake, which tending to stabilize throughout the remainder of the experiment. In the final stages of the process a decrease in the amount of consumed oxygen was noted, but this was due to the methodology used.

The effect of microbial degradation in the regulation of DOC concentrations in aquatic ecosystems is directly related with $\mathrm{k}_{\mathrm{D}}$. It is supposed that the fractions of DOC with high $\mathrm{k}_{\mathrm{D}}$ (Table 1) (short half-time) are present in the Infernão Lagoon at low concentrations. Due to their high $\mathrm{k}_{\mathrm{D}}$, these fractions do not tend to accumulate in the ecosystem. In contrast, fractions with low $\mathrm{k}_{\mathrm{D}}$ (long half-time) probably remain unaffected in the lagoon for long periods and, consequently, present the highest concentrations. Therefore, the different DOC fractions and their $\mathrm{k}_{\mathrm{D}}$ directly affect carbon recycle quality and quantity in the lagoon.

TABLE 1

Experimental results and parameters of the oxygen uptake model. Where: TOC $_{i}=$ total organic carbon in the beginning of experiment $(\approx$ DOC $) ;$ TOC $_{f}=$ final organic carbon $($ after 80-d); DOC $=$ dissolved organic carbon at the end of the experiment; POC $\left(\right.$ TOC $\left._{\mathrm{f}}-\mathrm{DOC}_{\mathrm{f}}\right)=$ particulate organic carbon; IN = inorganic carbon (mineralized); OC = total amount of oxygen uptake; $S C=$ global stoichiometric coefficient; $k_{\mathrm{D}}=$ oxygen uptake coefficient; $t_{1 / 2 \mathrm{D}}=$ oxygen uptake half-time.

\begin{tabular}{|c|c|c|c|c|c|c|c|c|c|}
\hline Substrate & $\begin{array}{c}\mathrm{TOC}_{\mathrm{i}} \\
\left(\mathrm{mg} \mathrm{L}^{-1}\right)\end{array}$ & $\begin{array}{c}\operatorname{TOC}_{f} \\
\left(\mathrm{mg} \mathrm{L}^{-1}\right)\end{array}$ & $\begin{array}{c}\mathrm{DOC}_{\mathrm{f}} \\
\left(\mathrm{mg} \mathrm{L}^{-1}\right)\end{array}$ & $\begin{array}{c}\mathrm{POC}_{\mathrm{f}} \\
\left(\mathrm{mg} \mathrm{L}^{-1}\right)\end{array}$ & $\begin{array}{c}\text { IN } \\
\left(\mathrm{mg} \mathrm{L}^{-1}\right)\end{array}$ & $\begin{array}{c}\mathrm{OC} \\
\left(\mathrm{mg} \mathrm{L}^{-1}\right)\end{array}$ & $\begin{array}{c}\text { SC } \\
(\mathrm{OC} / \mathrm{IN})\end{array}$ & $\begin{array}{c}\mathbf{k}_{\mathrm{D}} \\
\left(\mathrm{day}^{-1}\right)\end{array}$ & $\begin{array}{r}\mathbf{t}_{1 / 2 \mathrm{D}} \\
\text { (day) }\end{array}$ \\
\hline FA - S. cubensis & 30.84 & 21.58 & 20.61 & 0.97 & 9.26 & 14.56 & 1.57 & 0.282 & 2.45 \\
\hline HA - S. cubensis & 31.65 & 26.52 & 26.26 & 0.26 & 4.13 & 4.24 & 0.82 & 0.178 & 3.88 \\
\hline FA - sediment & 33.48 & 19.30 & 18.83 & 0.47 & 14.18 & 33.76 & 2.38 & 0.130 & 5.31 \\
\hline HA - sediment & 29.29 & 24.83 & 23.95 & 0.88 & 4.46 & 4.27 & 0.96 & 0.255 & 2.71 \\
\hline FA - DOM & 36.61 & 24.07 & 22.63 & 1.44 & 12.54 & 8.36 & 0.67 & 0.299 & 2.31 \\
\hline FA - C. piauhyensis & 27.49 & 20.99 & 17.04 & 3.95 & 20.78 & 17.04 & 2.62 & 0.123 & 5.62 \\
\hline
\end{tabular}

TABLE 2

Mineralization ( $k_{1}$ ), POC formation $\left(k_{2}\right)$, and RHS formation $\left(k_{3}\right)$ coefficients derived from $k_{\mathrm{D}}\left(\approx \mathrm{k}_{\mathrm{T}}\right)$ and the experimental results.

\begin{tabular}{|l|c|c|c|}
\hline \multicolumn{1}{|c|}{ Substrate } & $\mathbf{k}_{\mathbf{1}}$ & $\mathbf{k}_{\mathbf{2}}$ & $\mathbf{k}_{\mathbf{3}}$ \\
\hline FA - S. cubensis & 0.084 & 0.009 & 0.189 \\
\hline HA - S. cubensis & 0.029 & 0.002 & 0.147 \\
\hline FA - sediment & 0.055 & 0.002 & 0.073 \\
\hline HA- sediment & 0.039 & 0.008 & 0.208 \\
\hline FA - DOM & 0.071 & 0.002 & 0.226 \\
\hline FA - C. piauhyensis & 0.042 & 0.005 & 0.076 \\
\hline
\end{tabular}



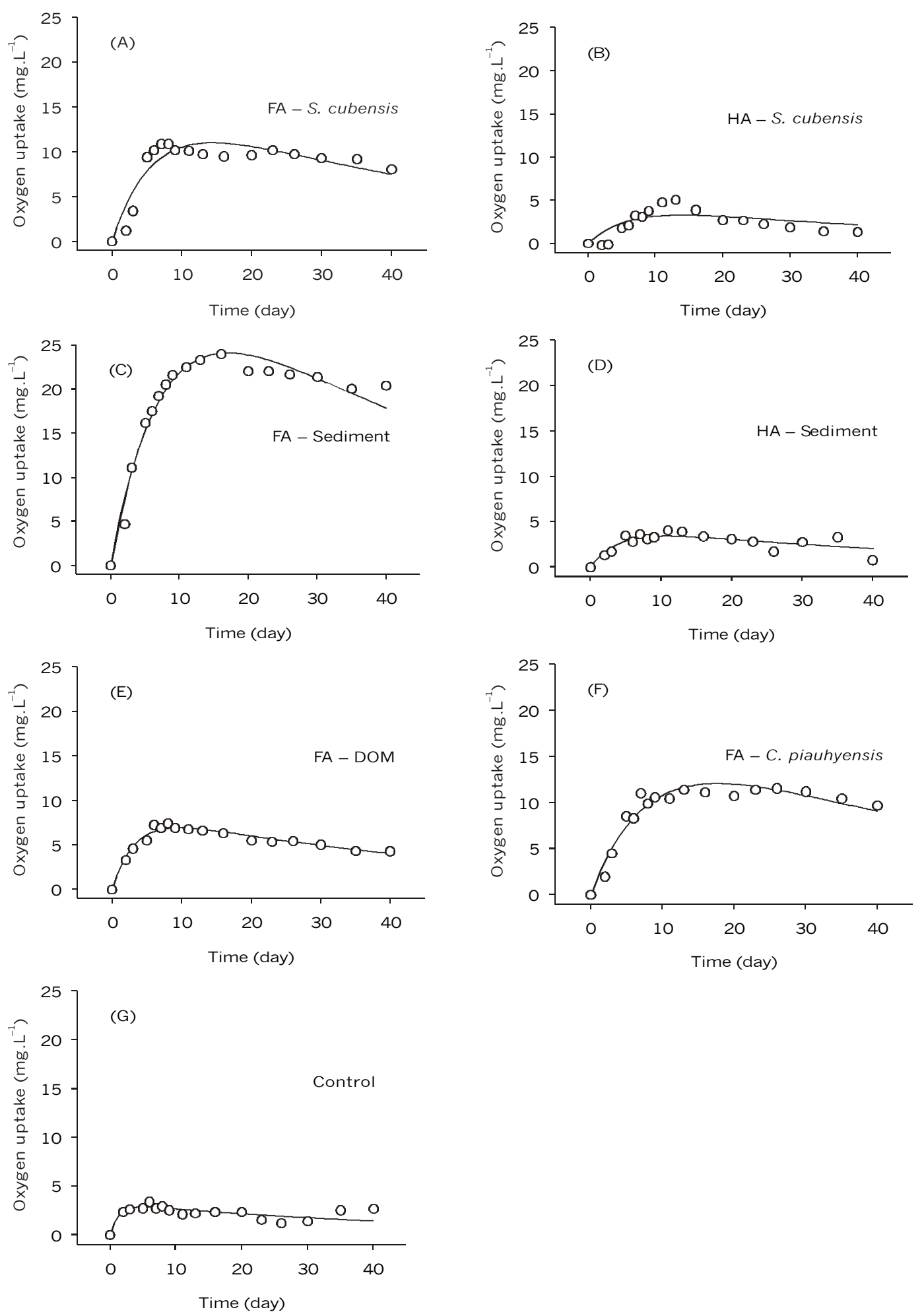

Fig. 1 - Kinetics of oxygen uptake during mineralization of FA and HA from different sources: (A and B) S. cubensis, (C and D) sediment, (E) DOM, (F) C. piauhyensis, and (G) control. 
The transformations of a given substrate present two important parameters: (i) the stoichiometry of the process and (ii) the reaction coefficients. The stoichiometry determines the extension of the mineralization process, presenting quantitative information on the consumption of reagents and products formed. The coefficients observed include the specific rates of substrate removal, oxygen uptake, and biomass production. These coefficients determine how fast changes occurred in the biochemical reactions (Levenspil, 1972), which is the most important quantity in any process analysis (Characklis, 1990).

Based on the evaluation of POC formation and DOC decay, a kinetics model was proposed to describe FA and HA aerobic mineralization of, where the substrate was assumed to be homogeneous. It was also taken for granted that the substrate could generate products by following three routes: (i) chemical/ biological oxidation by a $\mathrm{k}_{1}$, (ii) biosynthesis (according to $\mathrm{k}_{2}$ ), and (iii) restructuring of the substrate (HS rearrangement/polymerization of HS) according to a $\mathrm{k}_{3}$. In this model, $\mathrm{k}_{1}$ refers to the mineralization coefficient (oxidation), $\mathrm{k}_{2}$ means the biomass formation coefficient, and $\mathrm{k}_{3}$ refers to the rearrangement or redistribution of the initial substrate (Fig. 2).

The data indicated that the HS samples at the end of the experiment had lost carbon (ranging from $15.23 \%$ to $42.35 \%$ ), depending on the type of resource. These carbon amounts were transformed into $\mathrm{CO}_{2}$ through microbial metabolism, or were submitted to chemical/biological oxidation (Fig. 2).
The global stoichiometric coefficients varied as a function of HS origin and type (FA or HA). On average, FA presented stoichiometric coefficients 2.1 times higher than those for HA.

At the end of the experiments ( 80 days), the POC concentration was determined, and then used to obtain microbiologic yield estimates. Considering the different yields among the several substrates used in the experiment (Table 1), we inferred that at the early stages of the experiment, the biosynthesis levels were probably regulated by the substrate quality as well as the enzymatic capacity of the microbial community (Saunders, 1972; Wetzel \& Likens, 1991), where FA was the main carbon supplier. The registered yields of POC formation ( $0.76 \%$ to $3.94 \%$ ) were smaller than those observed by Cunha-Santino $\&$ Bianchini Jr. (2002), which varied from 13.6 to $15.7 \%$. These values indicate the prevalence, on the $80^{\text {th }}$ day of the experiment, of endogenous metabolism (internal cycling) over the biosynthesis process (microbial incorporation).

The model allows us to suppose that in the Infernão Lagoon system, humic substance mineralization can interfere in the global oxygen balance. This interference could be expressed by the changes in biochemical oxygen demand (BOD) during the aerobic mineralization of these substances. Regarding the high values of OC (e.g., FA (sediment)) verified in this study, we presume that the FA generates higher oxygen deficits than does the HA. In contrast, the OC during the mineralization of HA requires, on average, 4.3 times less oxygen.

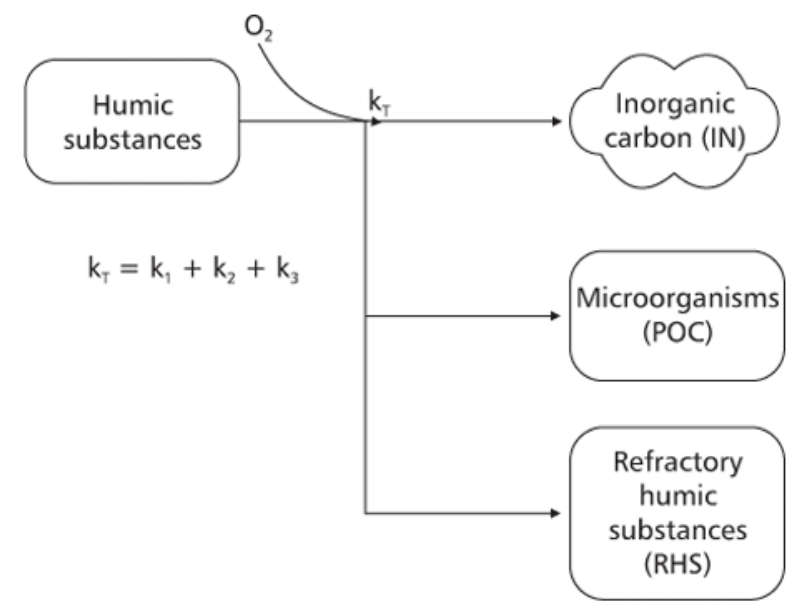

Fig. 2 - Conceptual kinetic model for decomposition of humic substances. 
Studies made by Cunha \& Bianchini Jr. (2001), on the humification of these plants in the Infernão Lagoon, showed the predominance of FA formation over HA. Considering the obtained results, the prevalence of HA as RHS, and its low $\mathrm{k}_{\mathrm{D}}$ value in relation to the FA, increases the probability of incorporation of this compound into the organic content of the permanent sediments. In summary, we may conclude that: i) the global stoichiometric and deoxygenation coefficients varied as a function of substrate origin and type and ii) on average, according to the proposed kinetic model, about $82.3 \%$ of HA stays in the lagoon as RHS, while for FA this value is $65.1 \%$. This means that during aerobic mineralization FA, rather than HA, provides the main resource for POC formation and chemical/biological oxidation (IN).

Acknowledgements - The authors thank Coordenadoria de Aperfeiçoamento de Pessoal de Nível Superior (CAPES) and Fundação de Amparo à Pesquisa do Estado de São Paulo (FAPESP) for financing this work (Process n. 95/00119-8). We are also indebted to Dr. Osvaldo N. Oliveira Júnior for his critical reading of the manuscript.

\section{REFERENCES}

BREZONIK, P. L., 1993, Chemical kinetics and process dynamics in aquatic systems. Lewis, Boca Raton, 754p.

CHAPRA, S. C. \& RECKHOW, K. H., 1983, Engineering approaches for lake management - mechanistic modeling. Butterworth/Ann Arbor, Woburn, 492p.

CHARACKLIS, W. G., 1990, Kinetics of microbial transformations. In: W. G. Characklis \& K. C. Marshall (eds.), Biofilms. John Wiley \& Sons, New York.

CUNHA-SANTINO, M. B. \& BIANCHINI Jr., I., 2002, Humic substance mineralization in a tropical oxbow lake (São Paulo, Brazil). Hydrobiologia, 468(1-3): 34-44.

CUNHA, M. B. \& BIANCHINI JR., I., 1998, Cinéticas de mineralização aeróbia de celulose e lignina durante a degradação de Cabomba piauhyensis e Scirpus cubensis. Acta Limnol. Brasil., 10(2): 59-69.

CUNHA, M. B. \& BIANCHINI Jr., I., 2001, Formação de compostos húmicos a partir da degradação de Scirpus cubensis e Cabomba piauhyensis. Acta Limnol. Brasil., 13(2): 35-43.

GODSHALK, G. L. \& WETZEL, R. G., 1978, Decomposition of aquatic angiosperms. III Zoltera MN Rina H. and a conceptual model of decomposition. Aquat. Bot., 5: 329-354.

GOTVAJN, A. Z. \& ZAGORC-KONCAN, J., 1999, Biodegradation studies as an important way to estimate the environmental fate of chemicals. Water Science Technol., 39(10-11): 375-382.

HAYES, M. H. B. \& SWIFT, R. S., 1978, The chemistry of soil organic colloids. In: D. J. E. Greenland \& M. H. B. Hayes (eds.), The chemistry of soil constituents. John Wiley \& Sons, Chichester.
HENZE, M., HARREMOËS, P., JANSEN, J. C. \& ARVIN, E., 1997, Wastewater treatment - biological and chemical processes. Springer-Verlag, Berlin, 383p.

JфRGENSEN, S. E., 1986, Fundamentals of ecological modelling. Developments in Environmental Modelling, 9. Elsevier, Amsterdam, 389p.

LEENHEER, J. A., 1981, Comprehensive approach to preparative isolation and fractionation of dissolved organic carbon from natural waters and wastewaters. Environ. Sci. Technol., 15: 578-587.

LEVENSPIEL, O., 1972, Chemical reaction engineering. John Wiley, New York, 211p.

McAVOY, D. C., GRADY JR., C. P. L., BLOK, J., FEIJEL, T. C. J., FEDERLE, T. W. \& LARSON, R. J. A., 1998 , Simplified modeling approach using microbial growth kinetics for predicting exposure concentrations of organic chemicals in treated waterwaste effluents. Chemosphere, 36(10): 2291-2304.

MALCOLM, R. L., 1985, Geochemistry of stream of fulvic and humic substances. In: G. R. Aiken, D. McKnight, R. L. Wershaw \& P. MacCarthy (eds.), Humic substances in soil, sediment and water. Wiley-Interscience, New York.

NOGUEIRA, F., ESTEVES, F. A. \& COUTINHO, O., 2000 Importância dos estandes flutuantes de macróftas aquáticas para as características limnológicas e para a ciclagem de nutrientes da lagoa do Infernão. In: J. E. Santos \& J. S. R. Pires (eds.), Estudos integrados em ecossistemas, $2^{2}$ vol. RiMa, São Carlos.

PIECZYNSKA, E., 1993, Detritus and nutrient dynamics in the shore zone of lakes: a review. Hydrobiologia, 251: 49-58.

PRESS, W. H., TEUKOLSKY, S. A., VETTERLING, W. T. \& FLANNERY, B. P., 1993, Numerical recipes in C: the art of scientific computing. Cambridge University Press, New York, 994p.

RYHÄNEN, R., 1968, Die Bedeutung der Humussubstangen im Stoffhaushalt der Gewässer Finnlands. Mitt. Int. Ver Theor. Angerw. Limnol., 14: 168-178.

SAUNDERS, G. W., 1972, The transformation of artificial detritus in lake water. Men. Inst. Ital. Idrobiol., 29: 261-288.

STEVENSON, F. J., 1982, Humus chemistry. Wiley, New York, $443 p$.

STUMM, W. \& MORGAN, J. J., 1981, Aquatic chemistry. WileyInterscience, New York, 789p.

THURMAN, E. M., 1985, Organic geochemistry of natural waters. Nijhoff/Junk Po., Netherlands, 497p.

WETZEL, R. G. \& LIKENS, G. E., 1991, Limnological analyses. Springer-Verlag, New York, 391p.

WETZEL, R. G., 1992, Gradient-dominated ecosystems: sources and regulatory functions of dissolved organic matter in freshwater ecosystems. Hydrobiologia, 229: 181-198.

WETZEL, R. G., 1995, Death, detritus and energy flow in aquatic ecosystems. Freshwater Biol., 33: 83-89. 